\title{
Evaluation of Accelerated Mineral Carbonation Efficiency Using Industrial By-products and Estimation of Its Domestic Carbon Dioxide Reduction Potential
}

\author{
Sangmin Lee ${ }^{1+\odot} \cdot$ Seong Min Yeon ${ }^{2 \oplus} \cdot$ Sokhee P. Jung ${ }^{3 \oplus}$ \\ ${ }^{1}$ Department of Environmental Engineering, Kongju National University, 1223-24 Cheonan-Daero, Cheonan 31080, Republic of Korea \\ ${ }^{2}$ Youngjin Environmental tech, Republic of Korea \\ ${ }^{3}$ Department of Environment and Energy Engineering, Chonnam National University, Gwangju 61186, Republic of Korea
}

(Received October 29, 2021; Revised January12, 2022; Accepted January 20, 2022)

Objectives: Cement Kiln Dust (CKD), a cement industrial by-product, was used in this study to improve the effectiveness of $\mathrm{CO}_{2}$ removal and increase the production of precipitate calcium carbonate (PCC) in the accelerated mineral carbonation process, differentiating injection flow rate of alkaline agent into the process. Further, CKD, slag, waste cement powder (WC), coal fly ash (CFA) which are mainly used for mineral carbonation, were also compared for their total $\mathrm{CO}_{2}$ removal capability by the year.

Methods: The morphology and composition of CKD were analyzed using FE-SEM, EDS and XRD to evaluate its applicability to mineral carbonation, and $\mathrm{CKD}$ extract and $1 \mathrm{~N} \mathrm{NaOH}$ were added into the reactor with the flow rate range of 1.1 to $3.0 \mathrm{~mL} / \mathrm{min}$ for longer reaction time. And DTA was carried out for purity analysis of PCC. Last, for annual $\mathrm{CO}_{2}$ removal potential evaluation, CKD, slag, WC and CFA was compared based on the result from this and previous researches.

Results: Result showed that $1 \mathrm{~N} \mathrm{NaOH}$ injection at flow rate of 1.1, 2.0, $3.0 \mathrm{~mL} / \mathrm{min}$ accelerated the $\mathrm{CO}_{2}$ removal by the $61.7,77.2,41.5 \%$ and $48.2,52.2,54.3 \mathrm{~g}$ of PCC was generated respectively. The annual amount of industrial by-product in Korea is 26,664,893 tons/year, 8,000,000 tons/year, 2,531,750 7,595,250 tons/year and 884,854 tons/year, respectively, in order of Slag, CFA, CKD, waste concrete fine powder (WC). Thus, the annual removal of $\mathrm{CO}_{2}$ could be estimated in order of $\mathrm{CKD}>\mathrm{Slag}>\mathrm{CFA}>\mathrm{WC}$.

Conclusion: CKD is a fine powder form with a high specific surface area, high calcium content, and high alkalinity. Therefore, $\mathrm{CKD}$ is superior to waste concrete or slag in mineral carbonation in removing $\mathrm{CO}_{2}$ and generating PCC. Considering the annual amount of $\mathrm{CO}_{2}$ removal when applying industrial by-products to the CCUS process, CKD and slag are considered the most economical mineral carbonation materials.

Keywords: Mineral carbonation, Cement kiln dust, alkali addition, Carbon capture utilization and storage, Precipitated calcium carbonate

The Korean text of this paper can be translated into multiple languages on the website of http://jksee.or.kr through Google Translator.

\footnotetext{
† Corresponding author

E-mail: sangmin@kongju.ac.kr

Tel: +82-41-521-9424 Fax: +82-41-552-0380

(c) 2022, Korean Society of Environmental Engineers
}

This is an Open Access article distributed under the terms of
the Creative Commons Attribution Non-Commercial License
(http://creativecommons.org/licenses/by-nc/4.0/) which permits provided the original work is properly cited. 


\title{
연구논문
}

\section{산업부산물을 이용한 가속광물탄산화 효율평가 및 국내 이산화탄소감축량 산정}

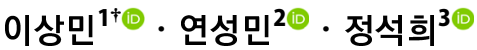 \\ ${ }^{1}$ 공주대학교 환경공학과 \\ ${ }^{2}$ 영진환경테크 \\ ${ }^{3}$ 전남대학교 환경에너지공학과
}

목적 : 시멘트산업공정 부산물인 $\mathrm{CKD}$ 를 사용한 가속광물탄산화 공정에서 $\mathrm{CO}_{2}$ 제거량과 침강성탄산칼슘(Pricipitated calcium carbonate, $\mathrm{PCC}$ ) 생성량을 향상하기 위해, 알카리제 주입 유속에 따른 $\mathrm{CO}_{2}$ 의 제거량과 침강성탄산칼슘(PCC) 발생량을 비교하였다. 그리고 광물탄산화에 쓰일 수 있는 산업부산물인 $\mathrm{CKD}$, 슬래그, 폐콘크리트미분말(Waste cement powder, $\mathrm{WC}), \mathrm{CFA}$ 의 $\mathrm{CO}_{2}$ 제거능과 $\mathrm{PCC}$ 생성성능을 비교하였고 이들의 국내 발생량 기준으로 연간 $\mathrm{CO}_{2}$ 제거 가능량을 평가하였다.

방법: $\mathrm{CKD}$ 의 광물탄산화 적용성을 평가하기 위해 $\mathrm{CKD}$ 미세분말의 미세구조와 성분을 FE-SEM, EDS 및 XRD를 통해 분석하였다. $\mathrm{PCC}$ 의 성분과 순도분석을 위해 XRD와 DTA 분석을 수행하였다. 이산화탄소의 제거성능을 평가 하기 위해 유입가스 $\left(5 \% \mathrm{CO}_{2}\right)$ 와 $\mathrm{CKD}$ 용출액을 이용하여 탄산화 반응을 수행하였다. $\mathrm{CO}_{2}$ 제거성능을 향상시키기 위해 $1 \mathrm{~N} \mathrm{NaOH}$ 를 $1.1,2.0,3.0 \mathrm{~mL} / \mathrm{min}$ 으로 주입 시 $\mathrm{CO}_{2}$ 제거율과 $\mathrm{PCC}$ 생성량을 평가하였다. 본 연구결과와 선행 연구자료를 이용하여 $\mathrm{CKD}$, 슬래그, 폐콘크리트, 및 $\mathrm{CFA}$ 의 연간 $\mathrm{CO}_{2}$ 제거 가능량을 산정하였다.

결과 및 토의: $\mathrm{CKD}$ 용출액과 알카리 첨가제를 함께 사용한 경우 $1 \mathrm{~N} \mathrm{NaOH}$ 의 주입속도를 $1.1,2.0,3.0 \mathrm{~mL} / \mathrm{min}$ 으 로 주입 시, $\mathrm{CO}_{2}$ 제거율은 각각 $61.7,77.2,41.5 \%$ 이었으며, $\mathrm{PCC}$ 발생량은 $48.2,52.2,54.3 \mathrm{~g}$ 이었다. 광물탄산화를 위한 산업부산물의 국내 발생량은 Slag, CFA, CKD, WC의 순으로 각각 26,664,893톤/년, 8,000,000톤/년, 2,531,750 톤/년 그리고 884,854 톤/년이고 $\mathrm{CO}_{2}$ 의 연간 제거 가능량을 산출하면 $\mathrm{CO}_{2}$ 의 연간 제거 가능량은 $\mathrm{CKD}>\mathrm{Slag}>\mathrm{CFA}$ $>\mathrm{WC}$ 순으로 산출된다.

결론 : $\mathrm{CKD}$ 는 미분형태로 비표면적이 높고 칼슘함량과 알카리도가 높으며 광물탄산화에서 폐콘크리트나 슬래그보 다 $\mathrm{CO}_{2}$ 제거와 PCC 생성율이 우수하다. 산업부산물을 탄소포집 및 활용저장(Carbon capture, utilization and storage, $\mathrm{CCUS}$ ) 공정에 적용 시 연간 $\mathrm{CO}_{2}$ 제거량을 고려할 때 국내 기준으로 $\mathrm{CKD}$ 와 슬래그가 가장 경제적인 광물탄산화 재료로 판단된다.

주제어: 광물탄산화, 시멘트킬른더스트, 알카리주입, 이산화탄소 포집 및 저장기술, 침강성 탄산칼슘

\section{1. 서 론}

2018년 IPCC special report에서 지구온난화가 최근 10년 동 안에 $0.2^{\circ} \mathrm{C}$ 상승하였고 현재의 온도상승 추세를 유지한다면 2032년에서 2052년 사이에 $1.5^{\circ} \mathrm{C}$ 상승할 것으로 예측하고 있 다. 지난 100 년 동안 한국의 평균기온은 $1.8^{\circ} \mathrm{C}$ 상승했는데 이 는 세계평균인 $0.8 \sim 1.2^{\circ} \mathrm{C}$ 보다 높은 값이다. ${ }^{1)} 2050$ 년까지 탄 소중립을 달성하기 위해서 정부는 기후와 에너지 정책의 상생 을 도모하고 효과적으로 이산화탄소를 제거하고 부가가치가 큰 부산물을 동시에 생산하여 경제성을 확보할 수 있는 탄소 포집 및 활용(carbon capture and utilization, $\mathrm{CCU}$ ) 기술의 개
발 및 상용화가 시급한 실정이다. $\mathrm{CCU}$ 기술은 아민계열의 화학적 흡수제 ${ }^{2}$ 를 이용하는 화학적 방법, 미세조류의 광합성 을 이용하는 생물학적 방법 그르리고 광물자원을 채굴 분쇄하 여 칼슘이나 마그네슘을 용출한 후 탄산화시키는 광물탄산화 법으로 ${ }^{4)}$ 분류할 수 있다.

광물탄산화는 1990년 Seifritz가 " $\mathrm{CO}_{2}$ binding" 개념을 최초 로 언급하였으며 이후 $\mathrm{Ca}$-탄산염 광물과 $\mathrm{Mg}$-탄산염 광물로 의 전환을 이용한 $\mathrm{CO}_{2}$ 고정화에 관한 연구가 진행되었다. ${ }^{5)}$ 초기 광물탄산화 연구는 주로 현무암과 같은 감람석, 사문석 및 규회석 등 천연 규산염 광물을 이용하여 진행되었다. ${ }^{\circ}$ 광 물탄산화를 위해서 천연광물에서 칼슘이나 마그네슘을 효율 
적으로 용출하기 위해서는 산성 조건이 필요하며 이후 $\mathrm{CO}_{2}$ 를 $\mathrm{PCC}$ 로 전화하려면 알칼리 조건이 필요하다. 이러한 상반된 $\mathrm{pH}$ 환경이 한 공정 속에 포함되어 있는 것은 광물탄산화 반응 속도를 저하시키는 문제를 가지고 있다. 이를 해결하기 위해 서 산성추출조건을 다시 알칼리 조건으로 전환해줄 필요가 있으며 다양한 방법을 통해 이를 구현하는 광물탄산화를 가속 광물탄산화라 한다.

현재 광물탄산화 기술 연구가 활발하게 진행되고 있으며 천 연광물 대신 폐콘크리트, ${ }^{7,8)}$ 슬래그, ${ }^{9-11)}$ Cement Kiln Dust $(\mathrm{CKD})^{12,13)}$ 및 Coal Fly Ash (CFA) $)^{14,15}$ 등의 산업부산물을 이 용한 연구가 진행되었다. 산업부산물의 사용은 재료의 채굴 및 파쇄 비용을 절감할 수 있고 생성된 침강성 탄산칼슘을 건축자재, 제지산업, 및 안료산업 등에 활용할 수 있다는 장점 이 있다.

한국지질자원연구원(2009)은 석고, 콘크리트, 슬래그, ALC, 플라이애쉬, 엑티노라이트 등의 다양한 원료광물을 이용하여 다양한 방식의 간접탄산화공정을 제시하였고 산업부산물(석 고, 슬래그)과 자연산광물(사문석, tremolite)에 대한 탄산화반 응을 비교·연구하였다. 석고의 탄산화 반응 시 탄산화율은 94 $\sim 97 \%$ 였고 슬래그의 경우 환원슬래그에서 $53 \sim 67 \%$, 고로슬 래그에서 $33 \sim 42 \%$ 로 나타났다. ${ }^{16)}$

폐콘크리트의 자원 재순환하는 과정에서 폐콘크리트를 파 쇄하고 분쇄하는 과정에는 강알카리성을 띠는 순환골재 미분 말이 발생하는데 이를 $\mathrm{CKD}$ 라 하고 $\mathrm{CKD}$ 를 재활용 방법들이 연구되고 있지만, 현재까지는 지정폐기물로 분류되어 중화처 리를 거쳐 매립 처분되고 있는 실정이다. ${ }^{17)}$

$\mathrm{CCU}$ 기술 적용에 있어서 안정성, 친환경성, 그리고 경제성 핵심 요소가 된다. 광물탄산화는 $\mathrm{CO}_{2}$ 를 열역학적으로 안정한 형태인 $\mathrm{CaCO}_{3}$ 침전물로 전환시키기 때문에 가역적으로 $\mathrm{CO}_{2}$ 로 환원되기는 매우 어렵고 지중저장기술에 비해 지진이나 자연재해로 인한 누출에 대한 안정성이 우수하다. 또한 화학 용매를 사용하는 화학적 흡수법에 비해 유기용매를 사용하지 않기에 친환경성이 크다. 그러나 현재 $\mathrm{CO}_{2}$ 배출권 거래에서 $\mathrm{CO}_{2}$ 1톤당 배출권 가격은 2019년 기준 국내가 4만원이고 $\mathrm{EU}$ 의 경우 €63로서 8.6만원 해당한다. 현재까지는 배출권거래가 격보다 저렴하게 광물탄산화를 수행하기는 어렵지만 세계적 으로 탄소중립의 물결과 더불어 배출권거래가격 추이가 €80 (11만원)을 상회할 것으로 판단되며 이 시점 이후 광물탄산화 의 경제성은 적용 가능한 수준으로 전환되기 시작할 것이다.

본 연구에서는 $\mathrm{CKD}$ 를 이용한 광물탄산화공정에서 $\mathrm{CO}_{2}$ 제 거량과 $\mathrm{PCC}$ 생성량을 제고하기 위해 알카리제 첨가와 유속에 따른 $\mathrm{CO}_{2}$ 의 제거량과 $\mathrm{PCC}$ 발생량을 비교하였고 광물탄산화 에 적용 시 경제성이 뛰어난 산업부산물인 $\mathrm{CKD}$, 슬래그, 폐 콘크리트 미분말, 그리고 $\mathrm{CFA}$ 의 국내 발생량을 기준으로 $\mathrm{CO}_{2}$ 제거 가능량을 비교·평가하였다.

\section{2. 연구방법 및 재료}

\subsection{CKD 발생과 광물탄산화}

시멘트를 구성하는 원료는 석회질, 점토질 등의 광물로서 시멘트의 주성분을 이루며 화학적 성분으로 $\mathrm{CaO}, \mathrm{SiO}_{2}$, $\mathrm{Al}_{2} \mathrm{O}_{3}$, 및 $\mathrm{Fe}_{2} \mathrm{O}_{3}$ 로 구성되어 있다. 석회석이 $1400 \sim 1500^{\circ} \mathrm{C}$ 에 서 소성과정을 통해 클링커가 생성되며 클링커는 $\mathrm{C}_{3} \mathrm{~S}(3 \mathrm{CaO}$. $\left.\mathrm{SiO}_{2}\right), \quad \beta-\mathrm{C}_{2} \mathrm{~S}\left(2 \mathrm{CaO} \cdot \mathrm{SiO}_{2}\right), \quad \mathrm{C}_{3} \mathrm{~A}\left(3 \mathrm{CaO} \cdot \mathrm{Al}_{2} \mathrm{O}_{3}\right)$, 및 $\mathrm{C}_{4} \mathrm{AF}$ $\left(4 \mathrm{CaO} \cdot \mathrm{Al}_{2} \mathrm{O}_{3} \cdot \mathrm{Fe}_{2} \mathrm{O}_{3}\right)$ 로 표현된다. $\mathrm{CKD}$ 는 시멘트 소성로 배 기가스에서 제거되는 미분형태의 고알칼리성 폐기물이다. $\mathrm{CKD}$ 의 많은 부분이 미 반응 원료이기 때문에, 일부 $\mathrm{CKD}$ 는 생산 공정으로 재사용되며 생산 공정으로 반환되지 않은 $\mathrm{CKD}$ 는 폐기물로서 매립 처분된다.

본 실험에서 사용된 $\mathrm{CKD}$ 는 강원 삼척시에 위치한 " $\mathrm{S}$ 시멘 트"의 시멘트 제조공정에서 석회석 원료분쇄 공정의 비산 분 진과 분쇄 원료가 킬른에 투입되기 전 예열기 상부에서 약 $550^{\circ} \mathrm{C}$ 정도의 비교적 낮은 온도로 가열하여 발생된 가스를 집진기에 의하여 포집한 미세 입자이며 본 실험에 사용한 $\mathrm{CKD}$ 의 평균입도는 $5 \mu \mathrm{m}$ 이고 최소크기는 $0.3 \mu \mathrm{m}$ 최대크기는 $50 \mu \mathrm{m}$ 로 나타났다.

\section{2. $\mathrm{CKD}$ 의 칼슘이온 추출효율}

$\mathrm{CKD}$ 를 $160 \mathrm{~g} / \mathrm{L}$ 농도로 수돗물에 혼합하여 용매의 농도가 $1 \mathrm{~N} \mathrm{HCl}$ 가 되도록 $\mathrm{HCl}$ 을 첨가하여 30 분간 교반상태에서 $\mathrm{Ca}^{2+}$ 을 추출 후 여과 후 여액을 광물탄산화 반응에 사용하였다. $\mathrm{CKD}$ 의 칼슘이온 추출 효율 $\left(\mathrm{X}_{\mathrm{ca}}\right)$ 는 식 (1)와 같이 정의된다.

$$
\mathrm{X}_{\mathrm{ca}}(\%)=\frac{W_{c a_{\text {etract }}} \times 100}{W_{c a_{\text {tatal }}}}
$$

여기서, $\mathrm{W}_{\text {ca } \_x t r a c t}$ 는 추출용액에 포함되어 있는 칼슘이온의 무 게 $(\mathrm{g})$ 이고 $\mathrm{W}_{\text {ca_total }}$ 는 본 실험에서 $\mathrm{CKD}$ 로부터 추출한 칼슘이 온의 총량이다.

$$
\mathrm{W}_{\text {ca_total }}=\frac{C_{a_{C K D}(\%)}}{100} \times W_{C K D}
$$

$\mathrm{W}_{\mathrm{CKD}}$ 는 용출시험에 사용된 $\mathrm{CKD}$ 의 무게 $(\mathrm{g})$ 이고 $\mathrm{C}_{\mathrm{ca} \_\mathrm{CKD}}(\%)$ 는 $\mathrm{CKD}$ 에 함유되어 있는 칼슘의 함량이다.

\subsection{FE-SEM, EDS, XRD 및 DTA 분석}

$\mathrm{CKD}$ 의 모양과 구성 원소를 측정하기 위해 FE-SEM (MIRA $\mathrm{LMH}, \mathrm{TESCAN}, \mathrm{Czech})$ 을 이용하여 분석하였다. SEM은 관 찰하고자 하는 물체의 표면으로 전자빔을 쏜 다음, 표면에서 반사되어 돌아오는 전자빔을 통해 얻은 이미지를 컴퓨터로 재구성하여 물체(시료)의 표면을 $3 \mathrm{D}$ 로 보여주는 것으로 $\mathrm{CKD}$ 의 모양을 확인하였다. EDS (X-flash4010, BRUKER, USA)로 


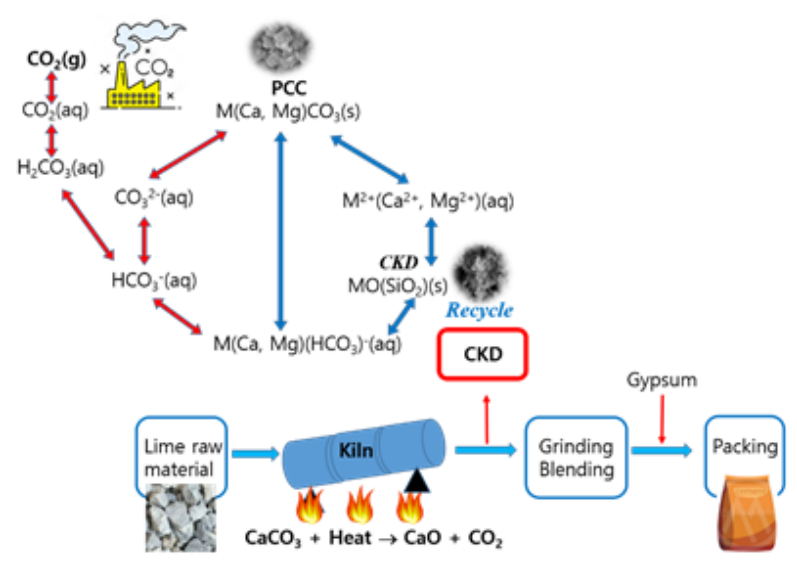

Fig. 1. A schematic diagram of cement industry process and mineral carbonation mechanism.

$\mathrm{CKD}$ 의 원소분석까지 진행하였다. 또한 침전된 탄산칼슘의 순도를 확인하기 위해 시차 열분석인 DTA (TA Instruments 社) 분석을 수행하였고 XRD (Rugaku 社)는 시료에 X선을 조 사하여 원자 주위에 있는 전자에 의해 산란 및 간섭 결과 일어 나는 회절을 해석하여 $\mathrm{PCC}$ 의 구성성분 및 결정성 등을 알 수 있다.

\subsection{Lab-scale 가속광물탄산화 공정}

\subsection{1. 가속광물탄산화 공정}

실험실 규모의 간접탄산화를 진행하기 위해서 광물탄산화 반응기를 Fig. 1 과 같이 설계 제작하였다. 공기와 $\mathrm{CO}_{2}$ 를 $\mathrm{MFC}$ (Mass Flow Controller)로 혼합하여 $5 \% \mathrm{CO}_{2}$ 를 광물탄산화 반 응기로 유입시키고 광물탄산화 반응기로 유입된 $5 \% \mathrm{CO}_{2}$ 가 스는 $\mathrm{CKD}$ 용출액과 탄산화반응이 이루어진다. 광물탄산화 반응 진행 중 $\mathrm{pH}$ 변화를 관찰하기 위해 반응기에 $\mathrm{pH}$ 센서를 설치하였다. 반응기로부터 배출되는 $\mathrm{CO}_{2}$ 가스는 $\mathrm{CO}_{2}$ 센서로 유입되고 DAQ system을 통해 실시간으로 데이터를 저장한

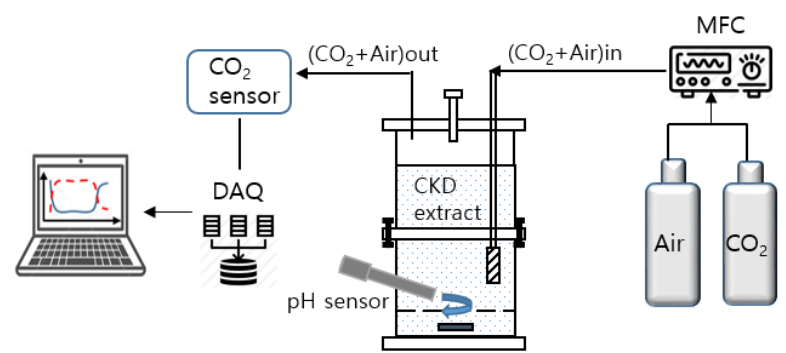

Fig.2. An experimental schematic diagram of lab-scale indirect mineral carbonation process.

다. $\mathrm{CO}_{2}$ 유입관을 통해 유입된 $5 \% \mathrm{CO}_{2}$ 가스는 그 관에 연결 된 디퓨저를 통과하면서 작은 버블로 분산되고 분산된 작은 $5 \% \mathrm{CO}_{2}$ 가스 버블은 반응기 안의 $\mathrm{CKD}$ 용출액과 접촉하면서 수면으로 상승하게 되고 수면 밖으로 배출된 가스는 가스유출 구로 나가 $\mathrm{CO}_{2}$ 센서로 이동하게 된다.

광물탄산화 공정은 $\mathrm{CKD}$ 용출액에 $\mathrm{CO}_{2}$ 가스를 $400 \mathrm{~mL} / \mathrm{min}$ 으로 주입하여 $\mathrm{CO}_{2}$ 의 배출농도가 유입농도와 동일하게 될 때 까지 탄산화 반응을 진행하였고 $\mathrm{CKD}$ 용출액에 $1 \mathrm{~N} \mathrm{NaOH}$ 를 각각 $1.1 \mathrm{~mL} / \mathrm{min}, 2.0 \mathrm{~mL} / \mathrm{min}, 3.0 \mathrm{~mL} / \mathrm{min}$ 으로 주입시켜 $\mathrm{NaOH}$ 주입속도에 따른 $\mathrm{CO}_{2}$ 제거량과 $\mathrm{PCC}$ 생성량을 측정하 였다.

\subsection{2. 이산화탄소 제거량 및 제거율 산정}

$\mathrm{CO}_{2}$ 제거량은 광물탄산화 반응기로 공급된 $\mathrm{CO}_{2}$ 유량에 $\mathrm{CO}_{2}$ 포집율을 곱해서 계산하였다. 여기서 $\mathrm{CO}_{2}$ 공급량은 $\mathrm{CO}_{2}$ 배출농도 곡선에서 $\mathrm{CO}_{2}$ 유량에 총 반응시간을 곱해 산정한 면적으로 $\mathrm{CO}_{2}$ 유입부피를 구한 후 이를 질량으로 환산하여 $\mathrm{CO}_{2}$ 공급량 $(\mathrm{g})$ 을 구했다. 여기에 $\mathrm{CO}_{2}$ 배출농도 곡선에서 공 급된 $\mathrm{CO}_{2}$ 농도(\%)에 총반응시간을 곱하여 나온 사각형의 면 적에서 $\mathrm{CO}_{2}$ 배출농도 곡선 아래부분의 면적을 sigmaplot 적분 함수를 이용하여 산정한 후 이를 빼주면 $\mathrm{CO}_{2}$ 배출농도 곡선

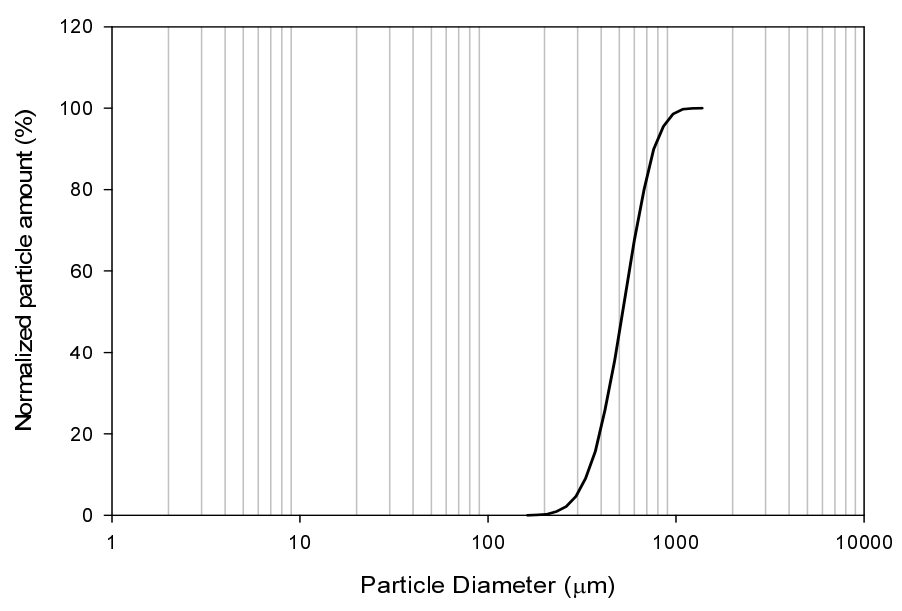

(a) PSA analysis

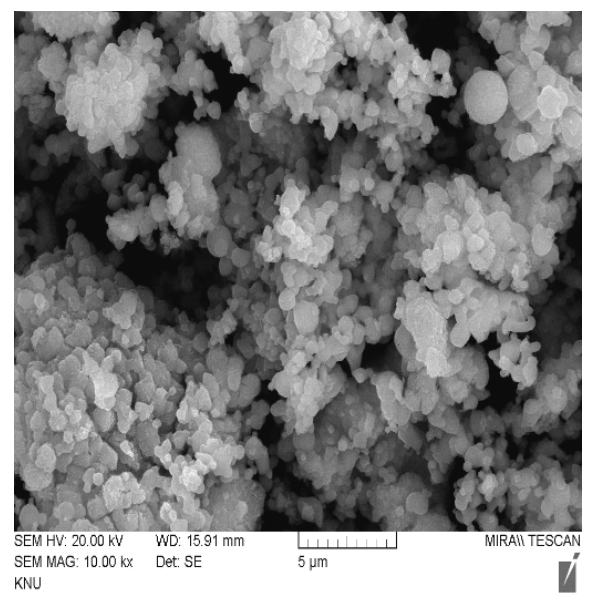

(b) FE-SEM $(10000 x)$

Fig. 3. Particle size distribution and FE-SEM image of CKD for mineral carbonation. 
윗부분의 면적이 나오는데 이를 위 사각형의 면적으로 나눈값 을 $\mathrm{CO}_{2}$ 제거율로 정의하여 산출하였다.

$\mathrm{CO}_{2}$ 고정량

$=\mathrm{CO}_{2}$ 공급량 $\left(\frac{L}{22.4 \mathrm{~L}} \frac{1 \mathrm{~mol}}{\mathrm{~mol}}\right) \times \mathrm{CO}_{2}$ 포집율 $(\%)$

$=\mathrm{CO}_{2}$ 유량 $\times$ 반응시간 $\times$

최종배출평형농도* 반응시간 $-\mathrm{CO}_{2}$ 배출곡선의 적분값 최종배출평형농도*반응시간

\section{3. 연구결과}

\subsection{CKD의 물리화학적 특성}

$\mathrm{CKD}$ 입자의 입도 분석결과 최소입도는 $182 \mu \mathrm{m}$, 최대입도 는 $1,379 \mu \mathrm{m}$, 중앙값은 $520 \mu \mathrm{m}$, 평균입도는 $513 \mu \mathrm{m}$ 이다. 입 경중 가장 많은 비율을 차지하는 것은 $599 \mu \mathrm{m}$ 의 입자로서 $14.712 \%$ 의 비율로 $\mathrm{CKD}$ 의 입도 분포 중 가장 많은 비율을 차지하는 것을 알 수 있다.

\section{2 간접광물탄산화를 위한 $\mathrm{CKD}$ 의 $\mathrm{Ca}^{2+}$ 용출특성}

\subsection{1. 용출용매 농도에 따른 $\mathrm{CKD}$ 의 $\mathrm{Ca}^{2+}$ 용출 특성}

Fig. 4는 $\mathrm{HCl}$ 무기용매를 농도별로 적용하여 $\mathrm{CKD}$ 분말에 서 해리된 $\mathrm{Ca}^{2+}$ 농도를 나타낸 것이다. $\mathrm{CKD}$ 는 $\mathrm{HCl}$ 용매의 농도가 증가함에 따라 $\mathrm{Ca}^{2+}$ 의 농도가 선형적으로 증가하는 경 향을 나타냈고 $\mathrm{R}^{2}=0.992$ 로 매우 높은 상관성을 보여주었다. $2.0 \mathrm{M} \mathrm{HCl}$ 용매로 30 분간 $\mathrm{CKD}$ 를 용출할 때 $23.7 \mathrm{~g} / \mathrm{L}$ 의 $\mathrm{Ca}^{2+}$ 농도를 나타냈다.

Fig.5는 $\mathrm{CKD}$ 를 30 분간 용출한 후 남아있는 $\mathrm{CKD}$ 잔류물을 동일한 조건에서(1.0N HCl, $30 \mathrm{~min}$ 용출, 상온) 용출을 반복 하여 추가로 용출할 수 있는 $\mathrm{Ca}^{2+}$ 의 최대량을 평가하기 위해 진행한 결과이다. 1 차 용출 시 $\mathrm{Ca}^{2+}$ 농도는 $19,700 \mathrm{mg} / \mathrm{L}$ 를 나타냈고 30 분 용출 시점에서 평형 $\mathrm{pH}$ 는 12 를 나타내었다. 이는 1 차 용출시에는 투입한 $\mathrm{CKD}(160 \mathrm{~g} / \mathrm{L})$ 의 알카리도가 충

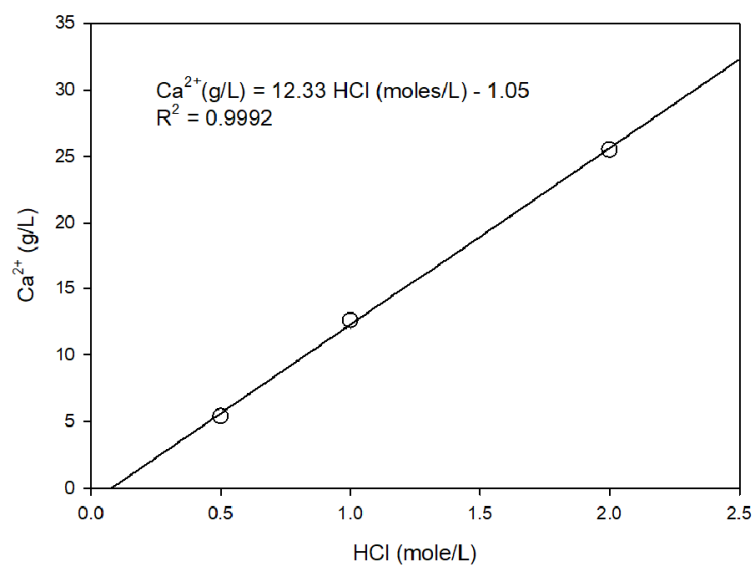

Fig. 4. The calcium ion extraction with $\mathrm{HCl}$ molar concentration.

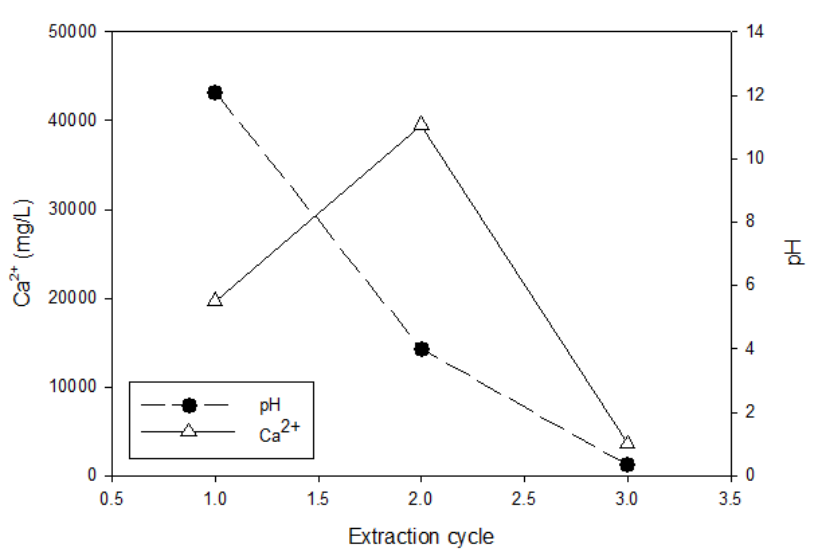

Fig. 5. A behaviour of calcium extraction with extraction cycles.

분히 존재하기 때문에 $1 \mathrm{~N} \mathrm{HCl}$ 을 투입한 직후 용매의 $\mathrm{pH}$ 가 잠시 하락하지만 곧 강알카리성 평형 $\mathrm{pH}$ 로 회복하기 때문이 다. 2차 용출 시 용출된 $\mathrm{Ca}^{2+}$ 농도는 $39,500 \mathrm{mg} / \mathrm{L}$ 로 상승하였 고 이때의 평형 $\mathrm{pH}$ 는 4 로 수렴하였다. 2 차에서 평형 $\mathrm{pH}$ 가 약산성으로 감소한 이유는 $\mathrm{CKD}$ 분말이 1차 용출에서 알카리 도가 우선적으로 소모되었기 때문에 잔류 알카리도가 $1 \mathrm{~N} \mathrm{HCl}$ 과의 중화반응으로 발생한 결과이다. 3 차 용출 시에는 용매의 평형 $\mathrm{pH}$ 는 0.5 정도의 강산성으로 수렴하였고 용출된 $\mathrm{Ca}^{2+}$ 농도는 $3,600 \mathrm{mg} / \mathrm{L}$ 였다. 이는 3 차에서는 알카리도가 거의 남 아 있지 않고 잔류 $\mathrm{Ca}^{2+}$ 함량도 적기 때문에 남은 고형물의 모두 해리됨에도 불구하고 용출 $\mathrm{Ca}^{2+}$ 농도가 2차에 비해 크게 작은 농도를 나타내었다.

\subsection{2. $\mathrm{CKD}$ 용출 잔류물의 $\mathrm{Ca}^{2+}$ 재 용출특성}

Fig.6은 $1 \mathrm{~N} \mathrm{HCl}$ 무기 용매로 $\mathrm{CKD}$ 를 용출하기 전후 이미지 를 FE-SEM으로 30,000 배의 배율로 촬영한 것이다. 용출 전 $\mathrm{CKD}$ 는 육각 판상구조 형상이 뚜렷하게 나타났으나 용출 후 $\mathrm{CKD}$ 는 표면에 존재하였던 판상 결정구조가 많이 사라지고 내부에 일부 발견되었다. 잔류물의 표면은 불규칙한 형태로 해리된 모습을 보여주고 있다.

Table 1는 EDS를 통해 분석한 용출 전후 $\mathrm{CKD}$ 의 표면분석 을 통한 성분을 나타낸 것이다. 주성분 원소로는 칼슘과 산소 로 나타났고 염소 성분도 $14.69 \%$ 까지 나타났다. 칼슘과 산소 는 $\mathrm{CaO}$ 를 구성하는 원소로 판단되며 염소이온은 시멘트 소성 로의 보조연료로 사용되는 폐플라스틱에서 기인한 것으로 판 단된다. 일반적으로 시멘트 제조공정에서 발생 $\mathrm{CKD}$ 의 $1 / 2$ 정 도는 시멘트 원료로서 재활용되고 나머지는 매립 등의 방법을 처분하고 있는 실정이다. 생활폐기물의 증가와 가용 매립장의 감소로 인해 폐기물의 처분에 대해 지자체에서 크게 고민하고 있으며 대안으로써 시멘트 생산 공정의 소성로(Kiln) 보조 연 료로 폐플라스틱을 연료화 하여 사용하려는 시도가 늘어나고 있다. 시멘트 소성로의 보조연료로 폐플라스틱의 사용량이 증 가하게 되면 $\mathrm{CKD}$ 의 염소 함량은 더욱 증가하게 되고 이는 

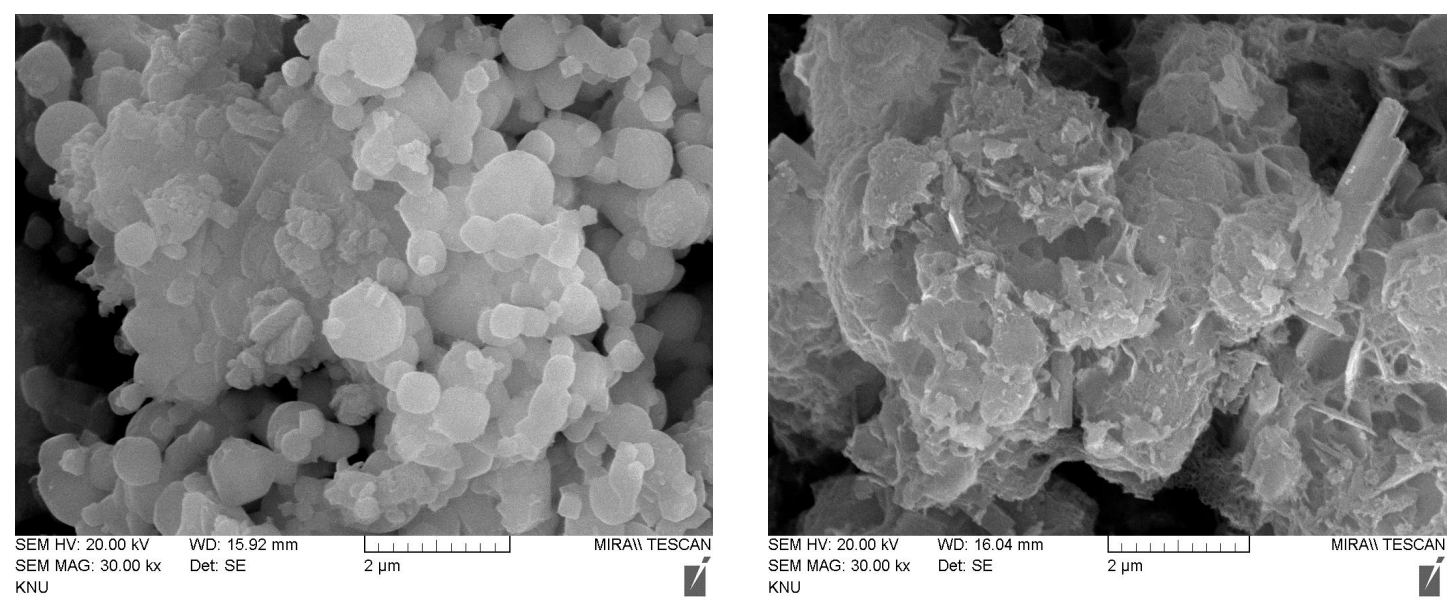

Fig. 6. A comparison of FE-SEM images of CKD (30000X). [Left: Before elusion of CKD with HCl, Right: After elusion of CKD with $\mathrm{HCl}]$

Table 1. Surface analysis of CKD before and after elution using EDS.

\begin{tabular}{ccc} 
Element of CKD & Before elusion & First elusion \\
\cline { 2 - 3 } $\mathrm{C}$ & Norm (wt, \%) & Norm (wt, \%) \\
\hline $\mathrm{O}$ & 5.29 & 5.90 \\
\hline $\mathrm{F}$ & 25.93 & 40.37 \\
\hline $\mathrm{Na}$ & 1.12 & - \\
\hline $\mathrm{Mg}$ & 0.79 & - \\
\hline $\mathrm{Al}$ & 0.91 & 1.62 \\
\hline $\mathrm{Si}$ & 1.85 & 2.53 \\
\hline $\mathrm{S}$ & 1.59 & 3.84 \\
\hline $\mathrm{Cl}$ & 1.39 & 0.90 \\
\hline $\mathrm{K}$ & 14.69 & 3.77 \\
\hline $\mathrm{Ca}$ & 17.21 & 0.62 \\
\hline $\mathrm{Fe}$ & 28.43 & 38.31 \\
\hline Total & 0.80 & 2.01 \\
\hline
\end{tabular}

시멘트 생산을 위한 재활용에 적합하지 않게 되기에 $\mathrm{CKD}$ 는 처분해야 할 폐기물로 발생량이 늘어날 것이다.

$\mathrm{EDS}$ 로 $\mathrm{CKD}$ 의 용출 전과 후의 성분을 분석한 결과 성분 구성비는 용출 전 $\mathrm{O}$ 는 $41.14 \%, \mathrm{Ca}$ 은 $18.01 \%, \mathrm{C}$ 는 $11.19 \%$, $\mathrm{K}$ 은 $11.18 \%$ 순이다. 용출 후 $\mathrm{O}$ 는 $56.62 \%, \mathrm{Ca}$ 은 $28.45 \%, \mathrm{C}$ 는 $11.03 \%, \mathrm{Si}$ 은 $3.07 \%$ 순이다.

Table 1에서 EDS를 이용하여 $\mathrm{CKD}$ 의 성분분석을 할 때 1차 용출 후 잔류고형물의 $\mathrm{Ca}$ 함량이 높아진 이유는 $\mathrm{CKD}$ 입자를 구성하는 원소 성분이 입자 표면과 내부까지 성분의 분포가 균질하지 않음을 의미한다. 용출 전 $\mathrm{Ca}$ 와 $\mathrm{Si}$, 그리고 $\mathrm{O}$ 의 함량 이 용출 후보다 낮고 $\mathrm{Cl}$ 와 $\mathrm{K}$ 함량이 용출 후보다 높게 나온 것은 $\mathrm{SiO}_{2}$ 나 $\mathrm{CaO}$ 분포가 $\mathrm{Cl}$ 이나 $\mathrm{K}$ 보다 내부에 높은 함량으로 존재한다고 판단된다. 이러한 추론을 보충하는 사실은 다음과 같다. CKD 발생은 시멘트킬른에 석회석과 보조연료로서 산
Table 2. Comparison of the amount of extracted $\mathrm{Ca}^{2+}$ and calcium content in CKD.

\begin{tabular}{|c|c|c|c|}
\hline Items & Unit & \multicolumn{2}{|c|}{ Value } \\
\hline CKD & $\mathrm{mg} / \mathrm{L}$ & \multicolumn{2}{|c|}{160,000} \\
\hline $\mathrm{Ca}^{2+}$ (by EDS) & $\%$ & 28.4 & 38.3 \\
\hline $\mathrm{Ca}_{\max }^{2+}$ & \multirow{5}{*}{$\mathrm{mg} / \mathrm{L}$} & 45,440 & 61,280 \\
\hline $1 \mathrm{st} \mathrm{Ca}^{2+}$ extract with virgin $\mathrm{CKD}$ & & \multicolumn{2}{|c|}{19,700} \\
\hline $2 \mathrm{nd} \mathrm{Ca}^{2+}$ extract with residue & & \multicolumn{2}{|c|}{39,500} \\
\hline $3 \mathrm{rd} \mathrm{Ca}{ }^{2+}$ extract with residue & & \multicolumn{2}{|c|}{3,600} \\
\hline sub total $\mathrm{Ca}^{2+}$ & & \multicolumn{2}{|c|}{62,800} \\
\hline $\mathrm{Ca}^{2+}{ }_{\text {ext }} / \mathrm{Ca}^{2+}{ }_{\text {max }}$ ratio & $\%$ & 138.2 & 102.5 \\
\hline $\mathrm{HCl}$ addition & N/cycle & \multicolumn{2}{|c|}{1} \\
\hline
\end{tabular}

업부산물과 생활폐기물이 함께 소각되며, 산업폐기물 중 염소 화합물이 소각되면서 시멘트 및 분진에 포함되는데 제조공정 에서 염화칼륨이 생성시멘트의 표면쪽에 주로 포함될 학률이 높게 되기 때문으로 판단된다.

Table 2는 CKD 분말을 $1 \mathrm{~N} \mathrm{HCl}$ 로 3차례 용출을 하여 완전 해리시켰을 때 용출 단계별로 해리된 $\mathrm{Ca}^{2+}$ 농도와 용출 전 총 $\mathrm{Ca}^{2+}$ 질량과 $\mathrm{EDS}$ 분석 결과 $\mathrm{Ca}^{2+}$ 함량과 비교한 결과이다. $\mathrm{EDS}$ 분석 결과 $\mathrm{CKD}$ 의 $\mathrm{Ca}^{2+}$ 함량은 $28.4 \sim 38.3 \%$ 이고 실 험에 사용된 $\mathrm{CKD}$ 는 $160 \mathrm{~g} / \mathrm{L}$ 이므로 $\mathrm{CKD}$ 내 총 $\mathrm{Ca}^{2+}$ 함유량 은 45,440 61,280 mg Ca${ }^{2+}$ 이다. 3 차례의 용출을 통해 발생 한 $\mathrm{Ca}^{2+}$ 농도는 $19,700,39,500$, 그리고 $3,600 \mathrm{mg} \mathrm{Ca}{ }^{2+} / \mathrm{L}$ 이므 로 3 차에 걸쳐 $\mathrm{CKD}$ 가 완전 해리되었을 때 발생하는 총 $\mathrm{Ca}^{2+}$ 량은 $62,800 \mathrm{mg} \mathrm{Ca}^{2+}$ 이다. 따라서 3 차에 걸쳐 완전 해리시킨 $\mathrm{CKD}$ 로부터 발생한 $\mathrm{Ca}^{2+}$ 의 질량과 성분분석을 통해 제시된 $\mathrm{Ca}^{2+}$ 질량은 거의 일치하는 칼슘 물질 수지를 나타내고 있다. 일반적으로 광물탄산화를 할 때 직접탄산화의 경우 1 차 반응 후 잔류물을 폐기하고 간접 탄산화의 경우도 1 차 용출 후 잔 류물을 폐기하는 경우가 많다. 본 연구 결과에 의하면 투입되 는 무기 용매와 생성되는 칼슘이온의 양을 고려할 때 $\mathrm{CKD}$ 
Table 3. Comparison of mineral carbonation according to $\mathrm{NaOH}$ flow rates.

\begin{tabular}{cccc} 
Conditions & $\begin{array}{c}1 \mathrm{~N} \mathrm{NaOH} \\
(1.1 \mathrm{~mL} / \mathrm{min})\end{array}$ & $\begin{array}{c}1 \mathrm{~N} \mathrm{NaOH} \\
(2.0 \mathrm{~mL} / \mathrm{min})\end{array}$ & $\begin{array}{c}1 \mathrm{~N} \mathrm{NaOH} \\
(3.0 \mathrm{~mL} / \mathrm{min})\end{array}$ \\
\hline Saturation time $(\mathrm{h})$ & 17.25 & 45.15 & 136.33 \\
\hline $\mathrm{CO}_{2 \text {-inf. }}(\%)$ & 5.01 & 4.99 & 5.05 \\
\hline Initial pH & 11.83 & 12.29 & 12.81 \\
\hline $\mathrm{CO}_{2}$ removal $(\%)$ & 61.69 & 77.18 & 41.47 \\
\hline $\mathrm{CO}_{2}$ removal $(\mathrm{mol})$ & 0.49 & 1.65 & 6.47 \\
\hline Produced PCC $(\mathrm{g})$ & 48.18 & 52.16 & 54.28 \\
\hline Produced PCC $(\mathrm{mol})$ & 0.48 & 0.52 & 0.54 \\
\hline non-PCC $(\mathrm{mol})$ & 0.01 & 1.13 & 5.93 \\
\hline
\end{tabular}

미분의 경우 2 차까지 재용출을 하는 것이 $\mathrm{CKD}$ 의 활용을 극 대화하고 폐기물 발생량을 줄여 친환경적인 공정에 더 가깝게 접근할 수 있다고 판단된다.

\section{3. $\mathrm{NaOH}$ 알칼리 첨가제 주입 유속이 간접 광물 탄산화에 미치는 영향}

Fig.7과 Table 3은 $\mathrm{NaOH}$ 알카리 첨가제의 주입속도에 따른 광물탄산화 거동과 $\mathrm{PCC}$ 생성특성을 비교한 것이다. $\mathrm{CO}_{2}$ 주입 농도를 $5 \%$ 로 고정하고 알칼리 첨가제의 유속은 $1.1 \mathrm{~mL} / \mathrm{min}$, $2.0 \mathrm{~mL} / \mathrm{min}, 3.0 \mathrm{~mL} / \mathrm{min}$ 으로 각각 설정하였다. $1.1 \mathrm{~mL} / \mathrm{min}$ 에 서는 $\mathrm{CO}_{2}$ 제거율이 $61.69 \%$ 발생 $\mathrm{PCC}$ 는 $48.18 \mathrm{~g}$ 이 나왔다. $2.0 \mathrm{~mL} / \mathrm{min}$ 에서는 $\mathrm{CO}_{2}$ 제거율이 $77.18 \%$ 발생 $\mathrm{PCC}$ 는 52.16 $\mathrm{g}$ 이 나왔다. $3.0 \mathrm{~mL} / \mathrm{min}$ 에서는 $\mathrm{CO}_{2}$ 제거율이 $41.47 \%$ 발생 $\mathrm{PCC}$ 는 $54.28 \mathrm{~g}$ 이 나왔다.

$1 \mathrm{~N} \mathrm{NaOH}$ 주입속도에 따른 $\mathrm{CO}_{2}$ 제거량은 유입속도 순으로 $0.49,1.65,6.47 \mathrm{~mol} \mathrm{CO}$ 로 나타나서 주입속도의 증가에 따라 $\mathrm{CO}_{2}$ 제거량이 비례 증가함을 보여주고 있으나 $\mathrm{PCC}$ 생성량은 유입속도별로 $0.48,0.52,0.54 \mathrm{~mol}$ 로서 $\mathrm{NaOH}$ 주입속도가 큰 영향은 미치지 않았다. 이는 PCC의 형성이 활발하게 일어나

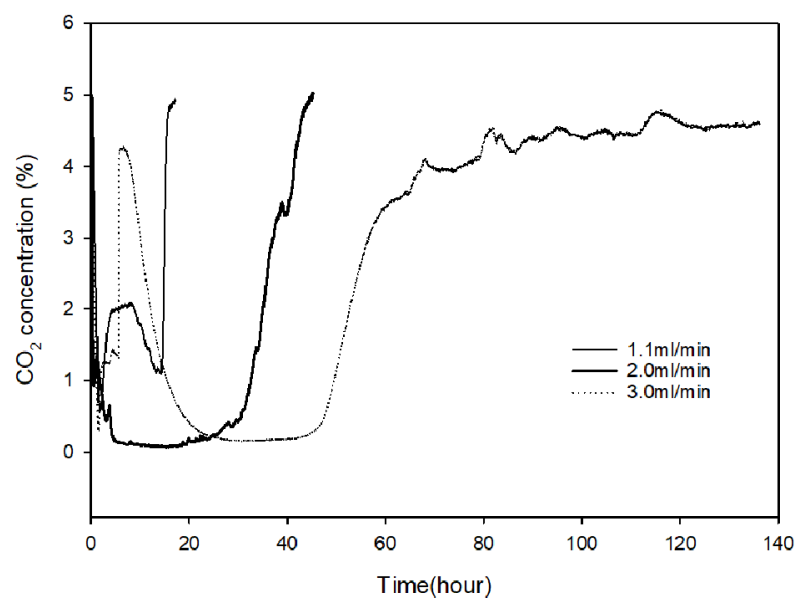

Fig.7. The effect of $\mathrm{NaOH}$ alkali addition speed on mineral carbonation.
는 $\mathrm{pH}$ 영역은 11 이상에서 발생하므로 $\mathrm{pH}$ 조건은 제한인자가 아니지만 $\mathrm{PCC}$ 형성에 필요한 $\mathrm{Ca}^{2+}$ 의 잔류량이 제한인자로 발 생하였기 때문이다. non-PCC는 총 $\mathrm{CO}_{2}$ 제거량 중 $\mathrm{PCC}$ 로 기 인하지 않고 제거된 양을 의미하는 것으로 " $\mathrm{CO}_{2}$ removal (mol)-Produced PCC (mol)"으로 산정한 것이고 이는 이산화 탄소가 탄산이나 중탄산의 형태로 액상으로 포집된 것으로 제거된 되었지만 열역학적으로 충분히 안정하지 않기 때문에 $\mathrm{pH}$ 조건에 따라 다시 방출될 위험이 존재하는 부분이다.

\subsection{PCC의 DTA 분석결과}

광물탄산화 반응결과 생성된 $\mathrm{PCC}$ 를 여과 및 건조 시켜 $\mathrm{DTA}$ 를 온도범위 $0 \sim 1,000^{\circ} \mathrm{C}$ 에서 실시하였다. 그 결과 $\mathrm{PCC}$ 의 무게는 초기 $100 \%$ 에서 $55 \%$ 로 감소하였고 $100 \% \mathrm{CaCO}_{3}$ 중 $44 \%$ 의 $\mathrm{CO}_{2}$ 가 열분해로 인해 제거된다고 가정하였을 때 $56 \%$ 가 남으므로 $\mathrm{PCC}$ 의 순도는 $100 \%$ 에 가까울 것으로 판단 된다.

\section{5. 산업부산물 재료별 광물탄산화 효율 및 적용성 비교}

Table 4는 다양한 산업부산물의 화학적 조성과 산업부산물 종류별 $\mathrm{CO}_{2}$ 제거량 그리고 $\mathrm{PCC}$ 생성량을 비교 분석한 것이 다. $\mathrm{CKD}$ 와 폐콘크리트 미분말의 조성은 본 연구에서 $\mathrm{XRD}$ 를 통해 분석한 결과이고 슬래그와 CFA는 $\operatorname{Han}$ (2011)의 문헌을 참조한 것이다. 광물탄산화에서 이산화탄소 제거에 사용되는 이온은 $\mathrm{Ca}^{2+}$ 이나 $\mathrm{Mg}^{2+}$ 이다. $\mathrm{Ca}^{2+}$ 이온이 포함된 $\mathrm{CaO}$ 성분을 비교하면 $\mathrm{CKD}$ 와 슬래그가 $40 \sim 44 \%$ 정도의 높은 함량을 가 지고 있고 폐콘크리트 미분말의 경우 $37 \%$ 로 두 번째로 높은 함량을 나타내고 있어 광물탄산화에 적용하기에 적합한 물 질로 판단된다.

산업부산물 종류별 단위 $\mathrm{CO}_{2}$ 제거량 및 $\mathrm{PCC}$ 발생량은 선행 연구 조건마다 온도 및 압력 등의 실험조건이 상이하기에 제 거량 및 발생량이 변동폭을 가질 수 있지만, 산업부산물을 광 물탄산화에 적용할 때 $\mathrm{CO}_{2}$ 를 제거량 및 $\mathrm{PCC}$ 발생량에 대한 통찰을 제공할 수 있다.

제철소에서 발생하는 슬래그는 크게 고로슬래그와 제강슬 래그로 분류되고 이들의 연간 국내 발생량은 2020년 기준 $26,664,893$ 톤/년이고 발생슬래그는 시멘트 원료로 $56.6 \%$, 도 로 및 성복토용으로 $31.5 \%$ 재활용하고 있다. ${ }^{21)}$ 제철슬래그는 재활용성이 매우 높은 특성을 나타내고 있지만 시멘트 원료나 성복토용 같은 저부가가치 용도로 대부분 사용되기 때문에 광물탄산화 재료로 전환 시 소요 비용이 저렴하고 강알카리성 의 화학적 특성과 구성 성분 중 $\mathrm{CaO}$ 가 약 $40 \%$ 내외를 차지하 고 있어 광물탄산화를 위한 원료물질로써 매우 좋은 특성을 가지고 있다. Table 4에 의하면 슬래그를 이용한 광물탄산화 물의 $\mathrm{CO}_{2}$ 제거 가능량은 $25 \sim 227 \mathrm{~kg}$ 톤 슬래그 범위로 분포하 고 이중 $\mathrm{BFS}$ 에 의한 광물 탄산화는 $227 \mathrm{~kg} \mathrm{CO}_{2} / \mathrm{ton} \mathrm{BFS}$ 이 고, $56 \mathrm{~kg} \mathrm{PCC} / \mathrm{ton} \mathrm{BFS}$ 를 생성했다. ${ }^{14)}$ Ghacham ${ }^{11)}$ 은 또한 1.1 
Table 4. Comparison of production and content of alkali metals in the various industrial by-products.

\begin{tabular}{|c|c|c|c|c|c|}
\hline \multirow{2}{*}{\multicolumn{2}{|c|}{ Industrial by-products }} & \multicolumn{2}{|c|}{ Content of alkali metal ( $\%)$} & \multirow{2}{*}{$\begin{array}{c}\mathrm{CO}_{2} \text { removal } \\
\left(\mathrm{Kg} \mathrm{CO}_{2} / \mathrm{t} \mathrm{SM}\right)\end{array}$} & \multirow{2}{*}{$\begin{array}{l}\text { PCC production } \\
\text { (Kg PCC/t SM) }\end{array}$} \\
\hline & & $\mathrm{CaO}$ & $\mathrm{MgO}$ & & \\
\hline \multirow{2}{*}{ Slag } & BF-slag & $40.0^{14)}$ & $8.6^{14)}$ & \multirow{2}{*}{$\begin{array}{c}52(\mathrm{EAF})^{17)} \\
227(\mathrm{BFS})^{18)} \\
25-98\left(^{1 \text { Slag })^{19)}}\right.\end{array}$} & \multirow{2}{*}{$56 \mathrm{~kg} \mathrm{PCC} / \mathrm{t} \mathrm{BFS}^{18}$} \\
\hline & Convert slag & $41.5^{14)}$ & $6.5^{14)}$ & & \\
\hline \multicolumn{2}{|c|}{ Waste concrete powder } & $37^{*}$ & $1.5^{*}$ & $40-120^{20)}$ & $68-204^{20)}$ \\
\hline \multicolumn{2}{|c|}{ Coal fly ash } & $7.5^{14)}$ & $1.7^{14)}$ & $31.1^{15)}$ & $170^{15)}$ \\
\hline \multicolumn{2}{|c|}{ Cement Kiln Dust } & $43.9^{*}$ & $0.7^{*}$ & $450^{*}$ & $340^{*}$ \\
\hline
\end{tabular}

${ }^{*}$ In this study

$\mathrm{MPa}$ 조건에서 $\mathrm{EAF}$ 슬래그 톤당 $52 \mathrm{~kg}$ 의 $\mathrm{CO}_{2}$ 가 제거되었다 고 보고했다. 국내 슬래그 발생량인 26,664,893톤/년을 적용 하면 ${ }^{21)}$ 국내 슬래그를 전량 광물탄산화에 사용한다고 볼 때 제거 가능한 $\mathrm{CO}_{2}$ 의 총량은 $666,622 \sim 2,616,160$ 톤 $\mathrm{CO}_{2} /$ 년으로 산정된다.

통계청 자료에 의하면 국내 시멘트 생산량은 2019년 기준 년간 50,635,000톤이고, 폐콘크리트 발생량은 44,242,695톤/ 년이다. ${ }^{22)} \mathrm{Jo}$ (2016) 등에 의하면 폐콘크리트에서 순환골재를 재활용할 때 발생하는 미분말은 폐콘크리트 발생량의 약 $2 \%$ 전후의 비율로 발생한다고 한다. ${ }^{23)}$ 2019년 폐콘크리트 발생량 인 44,242,695톤/년 중 순환골재를 제외하고 광물탄산화에 이용될 수 있는 폐콘크리트 미분말은 884,854 톤/년이 된다.

Table4에 의하면 폐콘크리트에 의한 $\mathrm{CO}_{2}$ 제거 가능량은 40 $\sim 120 \mathrm{~kg} \mathrm{CO} /$ ton WC의 범위와 $68 \sim 204 \mathrm{~kg} \mathrm{PCC} /$ ton WC의 $\mathrm{PCC}$ 생성을 보고하였다. ${ }^{20)}$ 이를 국내 폐콘크리트 미분말 발 생량을 적용하여 계산하면 연간 $\mathrm{CO}_{2}$ 제거 가능량은 35,394 $\sim 106,182$ 톤 $\mathrm{CO}_{2}$ /년에 해당된다. 폐콘크리트의 발생량과 이 로 인한 $\mathrm{CO}_{2}$ 저감량에 대한 보고는 문헌에 따라 차이가 있는 데 이는 폐콘크리트 발생량을 순환골재를 포함시켜 산정하는 경우와 순환골재를 제외하고 미분말로 평가하는가에 따라 발 생량의 차이가 발생하기 때문이다. 순환골재는 자갈과 같은 재료이기 때문에 광물탄산화에 적용하기에는 성분상 무리가 있다. 따라서 엄밀하게 평가한다면 순환골재를 제외한 방식의 산정방법이 광물탄산화 재료로서 현실적으로 타당하다고 판 단된다.

$\mathrm{CFA}$, 또는 석탄 연소 생산물(CCRs)은 석탄 연소 보일러 에서 배출되는 연소 연료의 미세한 미립자로 구성된 석탄 연소 물질이다. $\mathrm{CFA}$ 의 $\mathrm{CO}_{2}$ 제거 가능량 및 $\mathrm{PCC}$ 생성량은 31.1 $\mathrm{kg} \mathrm{CO}_{2} /$ ton $\mathrm{CFA}^{7)}$ 및 $170 \mathrm{~kg} \mathrm{PCC/ton} \mathrm{CFA.}{ }^{15)}$ 이를 국내 CFA 발생량인 $8,000,000$ 톤/년을 적용하여 ${ }^{24)}$ 연간 $\mathrm{CO}_{2}$ 제거 가능 량을 계산하면 240,000 톤 $\mathrm{CO}_{2}$ /년에 해당된다. $\mathrm{CKD}$ 는 시 멘트 생산량의 5 15\% 비율로 발생하므로 2019년 기준 시멘트 발생량은 $50,635,000$ 톤/년이므로 $\mathrm{CKD}$ 발생량은 $2,531,750$ 톤/년에서 7,595,250톤/년으로 추산할 수 있다. 이를 Table4의 단위 $\mathrm{CKD}$ 당 $\mathrm{CO}_{2}$ 제거량을 곱해 $\mathrm{CKD}$ 에 의한 연간
$\mathrm{CO}_{2}$ 제거량을 $1,139,288 \sim 3,417,863$ 톤/년으로 추산된다.

광물탄산화 재료로서 적용이 유망한 4 가지 산업폐기물의 연간 $\mathrm{CO}_{2}$ 제거 가능량을 평가하기 위해 산업폐기물의 국내 발생량을 조사한 결과 산업부산물의 단위 질량당 $\mathrm{CO}_{2}$ 제거 가능량은 $\mathrm{CKD}>\mathrm{Slag}>\mathrm{WC}>\mathrm{CFA}$ 순으로 나타났다. 이는 광 물탄산화 효율이 재료의 $\mathrm{Ca}^{2+}$ 및 $\mathrm{Mg}^{2+}$ 함량과 알카리도의 이 변수 함수이기 때문이고 이러한 측면에서 $\mathrm{CKD}$ 와 $\mathrm{Slag}$ 가 광 물탄산화에 유리한 특성을 가지고 있고 특히 $\mathrm{CKD}$ 는 입도가 작은 미립자 형태로 발생하고 높은 비표면적을 가지고 있는 장점이 있고 Slag의 경우는 반응속도를 증진시키기 위해서는 미분형태로 분쇄하는 작업이 추가된다는 단점이 있다. 국내 산업부산물의 연간 발생량은 $\mathrm{Slag}>\mathrm{CFA}>\mathrm{CKD}>\mathrm{WC}$ 순으 로 발생된다. Table4에서 제시한 산업폐기물 톤당 이산화탄 소 제거량 단위를 곱해 연간 $\mathrm{CO}_{2}$ 제거 가능량을 산출한 결과 $\mathrm{CO}_{2}$ 의 연간 제거 가능량은 $\mathrm{CKD}>\mathrm{Slag}>\mathrm{CFA}>\mathrm{WC}$ 순으로 높게 평가되었다.

\section{4. 결 론}

1. 광물탄산화의 원료 물질로서 시멘트 산업의 부산물인 $\mathrm{CKD}$ 는 높은 알카리도와 작은 입도 특성으로 인해 빠른 반응 속도와 높은 $\mathrm{Ca}^{2+}$ 용출특성을 나타내고 $\mathrm{HCl}$ 무기용매의 농도 에 따라 $\mathrm{Ca}^{2+}$ 의 용출 농도가 선형적으로 증가하는 경향을 나 타냈고 $\mathrm{R}^{2}=0.992$ 였고, $2.0 \mathrm{M} \mathrm{HCl}$ 로 30 분간 $\mathrm{CKD}$ 를 용출할 때 $23.68 \mathrm{~g} \mathrm{Ca}^{2+} / \mathrm{L}$ 의 농도를 나타냈다.

2. $\mathrm{CKD}$ 의 칼슘용출 시 발생하는 잔류물의 경우 재용출을 통해 추가적인 $\mathrm{Ca}^{2+}$ 을 얻을 수 있었고 $\mathrm{CKD}$ 의 경제성을 최대 화하고 폐기물 발생량을 줄이기 위해 2 회 재용출을 하는 것이 높은 가성비를 나타냈다.

3. $\mathrm{CO}_{2}$ 제거량 및 효율을 향상시키기 위해 첨가제로 $1 \mathrm{~N}$ $\mathrm{NaOH}$ 를 유입속도별로 $1.1,2.0,3.0 \mathrm{~mL} / \mathrm{min}$ 으로 주입 시 각각 의 경우 $\mathrm{CO}_{2}$ 제거율은 $61.69,77.18$, 그리고 $41.47 \%$ 를 나타냈 으며 $48.19,52.16$, 그리고 $54.28 \mathrm{~g}$ 의 PCC가 발생하였다.

4. PCC 생성 몰질량은 유입속도별로 $0.48,0.52,0.54 \mathrm{~mol}$ 로 서 $\mathrm{NaOH}$ 주입속도가 큰 영향을 미치지 않았다. 이는 용액속 
에 $\mathrm{PCC}$ 형성에 필요한 $\mathrm{Ca}^{2+}$ 이 소진되어 잔류량이 제한인자 로 작용한 것으로 판단된다. 그리고 $\mathrm{PCC}$ 를 DTA 뷴석한 결 과 침전물의 $\mathrm{CaCO}_{3}$ 순도는 거의 $100 \%$ 에 가까운 고순도를 나타내었다.

5. 산업부산물의 국내 연간 발생량은 $\mathrm{Slag}>\mathrm{CFA}>\mathrm{CKD}>$ $\mathrm{WC}$ 순이고 이에 산업부산물의 톤당 이산화탄소 제거량 단위 를 곱해 연간 $\mathrm{CO}_{2}$ 제거 가능량을 산출한 결과 국내기준으로 $\mathrm{CO}_{2}$ 의 연간 제거 가능량은 $\mathrm{CKD}>\mathrm{Slag}>\mathrm{CFA}>\mathrm{WC}$ 순으로 높게 평가되었다.

\section{Acknowledgement}

이 논문은 2020 년도 정부(교육부)의 재원으로 한국연구재 단의 지원을 받아 수행된 기초연구사업임(No. 2020R1I1A3A 04037029). 또한, 2020년 공주대학교 학술연구지원사업의 연 구지원에 의하여 연구되었음.

\section{References}

1. M. R. Allen, O. P. Dube, W. Solecki, F. Aragón-Durand, W. Cramer, S. Humphreys, M. Kainuma, J. Kala, N. Mahowald, Y. Mulugetta, R. Perez, M. Wairiu, K. Zickfeld, IPCC SPECIAL REPORT: Global Warming of $1.5^{\circ} \mathrm{C}$, https://www.ipcc.ch/sr15/chapter/chapter-1/(2018).

2. S. Park, K. Song, H. Jo, Laboratory-scale experiment on a novel mineralization-based method of $\mathrm{CO}_{2}$ capture using alkaline solution, Energy, 124, 589-598(2017).

3. $\mathrm{H}-\mathrm{M}$. Oh, C-Y. Ahn, $\mathrm{CO}_{2}$ fixation and biodiesel production using microalgae, KIC News, 12, 1-9(2009).

4. A-H. A. Park, R. Jadhav, L-S. Fan, $\mathrm{CO}_{2}$ Mineral Sequestration: Chemically Enhanced Aqueous Carbonation of Serpentine, Can J. Chem. Eng., 81, 885-890(2003).

5. W. Seifritz, $\mathrm{CO}_{2}$ disposal by means of silicates, Nature, 345 , 486-486(1990).

6. S. C. Chae, J. Y. Nam, K. Ryu, Mineral Carbonation as a sequestration method of $\mathrm{CO}_{2}$ : Review, J. Geol. Soc. Korea, 45, 527-555(2009).

7. H-J. Ho, A. Iizuka, E. Shibata, H. Tomita, K. Takano, T. Endo, Utilization of $\mathrm{CO}_{2}$ in direct aqueous carbonation of concrete fines generated from aggregate recycling: Influences of the solid - liquid ratio and $\mathrm{CO}_{2}$ concentration, J. Clean Prod., 312, 127832(2021).

8. S. Lee, Y. J. Kim, J. M. Kim, C. H. Lee, J. K. Jeon, Effect of $\mathrm{pH}$ Adjusting Contactor on Indirect Carbonation Efficiency Using Waste Concrete, J. Korean Soc. Urban Env., 17, 65-75(2017).

9. R. Baciocchi, G. Costa, A. Polettini, R. Pomi, Influence of particle size on the carbonation of stainless steel slag for $\mathrm{CO}_{2}$ storage, Energy Procedia, 1, 4859-4866(2009).
10. E-E. Chang, S-Y. Pan, Y-H. Chen, H-W. Chu, C-F. Wang, P-C. Chiang, $\mathrm{CO}_{2}$ sequestration by carbonation of steelmaking slags in an autoclave reactor, J. Hazard. Mater., 195, 107-114(2011).

11. A. B. Ghacham, L-C. Pasquier, E. Cecchi, J-F. Blais, G. Mercier, $\mathrm{CO}_{2}$ sequestration by mineral carbonation of steel slags under ambient temperature: parameters influence, and optimization, Environ. Sci. Pollut. Res. Int., 23, 635-646 (2016).

12. S. Lee, Y. Kim, C. Choi, J. Lee, Characteristics of $\mathrm{CO}_{2}$ sequestration in indirect mineral carbonation (IMC) using cement kiln dust (CKD), J. Korean Soc. Urban Env., 18, 303-310(2018).

13. M-J. Kim, S. Y. Pak, D. Kim, S. Jung, Optimum conditions for extracting $\mathrm{Ca}$ from $\mathrm{CKD}$ to store $\mathrm{CO}_{2}$ through indirect mineral carbonation, KSCE J. Civ. Eng., 21, 629-635(2017).

14. S-J. Han, H. J. Im, J-H. Wee, Leaching and indirect mineral carbonation performance of coal fly ash-water solution system, Appl. Energy, 142, 274-282(2015).

15. G. Montes-Hernandez, R. Pérez-López, F. Renard, J. M. Nieto, L. Charlet, Mineral sequestration of $\mathrm{CO}_{2}$ by aqueous carbonation of coal combustion fly-ash, J. Hazard. Mater., 161, 1347-1354(2009).

16. Z. T. Yao, X. S. Ji, P. K. Sarker, J. H. Tang, L. Q. Ge, M. S. Xi, Y. Q. Xi, A comprehensive review on the applications of coal fly ash, Earth-Science Review, 141, 105-121(2015).

17. H. Konno, Y. Nanri, M. Kitamura, Effect of $\mathrm{NaOH}$ on aragonite precipitation in batch and continuous crystallization in causticizing reaction, Powder Technol., 129, 15-21(2003).

18. M. Mun, H. Cho, Mineral carbonation for carbon sequestration with Industrial Waste, Energy Procedia, 37, 6999-7005(2013).

19. M. Garside, Cement production global 2020 Statista, https://www.statista.com, September(2021).

20. USGS, Mineral Commodity Summaries 2020. US Geol Surv., https://pubs.usgs.gov, January(2020).

21. Korean Iron and Steel Association, https://www.kosa.or.kr, Septeber(2021).

22. KOSIS, Korean statistical information service, https://kosis.kr/ index/index.do, Septeber(2021).

23. M-K. Jo, D-G. Kim, Guidelines of recycled aggregates powder for recycling of construction wastes, Mag. RCR, 11, 26-29(2016).

24. D. S. Kim, G. S. Han, D-K. Lee, D-S. Kim, G. S. Han, D-K. Lee, Recycling of useful materials from fly ash of coal-fired power plant, Clean Technol., 25, 179-188(2019).

\section{Declaration of Competing Interest}

The authors declare that they have no known competing financial interests or personal relationships that could have appeared to influence the work reported in this paper. 


\section{Authors and Contribution Statement}

\section{Sangmin Lee}

Department of Environmental Engineering, Kongju National University, Professor, Conceptualization, Methodology, Writing original draft, Writing review and editing: ORCID (두 0000-0003 $-3284-8754$

\section{Seong Min Yeon}

Youngin Environmental tech., Staff Visualization, Writing original draft ORCID (C) 0000-0002-8425-4539

\section{Sokhee P. Jung}

Department of Environment and Energy Engineering, Chonnam National University, Professor, Writing - review and editing, ORCID 다 0000-0002-3566-5649 